\title{
The Effect of Education and Training on Performance Through Employee Job Placement Assessment
}

\author{
Adi Kusnawan *, Juhriansyah Dalle, Karyono Ibnu Ahmad \\ Master Program of Education Management, Universitas Lambung Mangkurat, Banjarmasin 70123 \\ Indonesia
}

Article history:

Submission November 2019

Revised April 2020

Accepted May 2020

${ }^{*}$ Corresponding author:

E-mail:

adi.kusnawan.st@gmail.com

\begin{abstract}
Education, training, and assessment of placement are essential for companies, therefore, this research aims to analyze the effect of training on job placement assessment. This emphasized the effect of education; and job placement assessment on employee performance; and also, education on employee performance through job placement assessment. Furthermore, the study was performed on 87 employees of PT. Gunung Limo and PT. Putra Sarana Transborneo, which became the sample size chosen randomly. The data obtained were grouped with the use of a questionnaire and subsequently evaluated using the path analysis. Besides, the result showed some effects of (1) education and (2) training on job placement assessment; (3) education, (4) training and (5) job placement assessment on performance; and also the effect of (6) education and (7) training on the employee's performance through job placement assessment by a company's education management unit.
\end{abstract}

Keywords: Education, training, performance, placement assessment

\section{Introduction}

The success of any organization is dependent on the ability of its employees to perform their duties effectively and efficiently. Mahsun (2006) defined this evaluation as an overview of an organization's ability to achieve its objectives, aim, mission, or target. Similarly, Tike (2014) stated that performance is the result of an organization's effort which is influenced by several factors.

Based on these definitions, that performance is the result of an individual or group's job in achieving an organization's aim within a specified period.

According to Mangkunegara (2010), define employee performance is the quality and quantity of work achieved by employees in carrying out their duties and responsibilities. Employee performance seeks to improve one's efficiency and work ethic which is carried out in various ways. Furthermore, Hasibuan
(2010) stated that an employee's performance is the result achieved by someone in carrying out their jobs based on their skill, and experience.

Based on the opinion of these experts, it is concluded that employee's performance is the result of actions aimed at achieving positive output. The measurement of this organization's performance is conducted using the performance assessment. Based on the above description, performance is the goals achieved following the criteria of an organization's standard. Performance is improved when there is a match between effort and ability.

Individual performance is also influenced by job satisfaction which is one's feelings to work. An evaluation known as performance appraisal is needed. Mangkuprawira (2011) reported that education and training is the process of teaching certain knowledge, skills, and attitudes for employees to become more 
skilled and able to carry out their responsibilities following standards.

According to Chaerudin (2019), the results of training programs are categorized based on the following impacts: (a)The positive impact which occurs when an employee's work performance increases due to training programs; (b) Zero impact occurs when there is no change in employee work performance after participating in the training; (c) Negative impacts due to interference with training programs and employee performance

From the opinion above it is concluded that when an employee undergoes training, their performance and motivation towards work, tend to improve. Performance is a way to check how suitable a job is for an individual. After training, employees tend to have adequate knowledge of their work performance.

From the opinion above it is concluded that when an employee undergoes training, their performance and motivation towards work, tend to improve. Performance is a way to check how suitable a job is for an individual. After training, employees tend to have adequate knowledge of their work performance.

According to Siswanto (2002), the academic achievement factor needs to be considered for job placement. An employee with a high academic record has to be placed in a job that needs great authority and responsibility, and vice versa. The skill and ability factor with the required job's qualification makes them learn the job quicker.

Pesiwarissa (2008) stated that the suitability of work placement for employees requires the educational knowledge or educational background to match the job description. Skill suitability is when an employee has the necessary technical, humanitarian, and conceptual knowledge to occupy the job position using indicators. Therefore, academic achievement in job placement has an impact on its efficacy. The right employee's placement yields a positive impact on the organization. Aldilaningsari et al. (2014) stated that job placement is the process of placing a suitable person into a certain position based on knowledge, ability, and skill.
According to Schuler \& Jackson (1997), its accuracy depends on the suitability between one's knowledge, skills, abilities, and compatibility between personality, preferences, and opportunities related to the company. Riyanto et al. (2017), defined it as a decisive process used to acquire competent employees needed by the company or organization to achieve its expected goals. Job placement is an important criterion capable of harnessing human results for the benefit of the company.

Based on said the above decryption, this research aims to determine the following objectives on job placement: (a) Deeply describe the relationship between employee training and skills; (b) Analyze the impact of education; (c) Analyze the effect of training; (d) Analyze the direct impact of education on the employee's performance; (e) Analyze the effect of training; (f) Analyze the relationship of job placement assessment to the employee's performance; (g) Analyze the effect of education on the employee's performance; (h) Using the employee job placement assessment to analyze the effect of training.

\section{Material and Methods}

The population of this study encompasses all employees of PT. Gunung Limo and PT. Putra Sarana Transborneo, in Banjarmasin, South Kalimantan, totaling up to 111 people. Furthermore, the ideal sample size for this research was calculated using the Slovin technique, with an error rate of $5 \%$, therefore only 87 employees were sampled. Besides, the selection was performed using a simple random sampling technique.

The validity of instrument used the Pearson Product Moment method and the test used the Corrected item-total correlation technique with IBM SPSS 25 for window. Variables in this research aim, education and training as independent variables, employee's performance as a dependent variable, and job placement assessment as an intervening variable. Moreover, the data collection required the distribution of questionnaires, and the result obtained was analyzed using the path analysis technique. Hence, the model of this path analysis is depicted in Figure 1 below. 


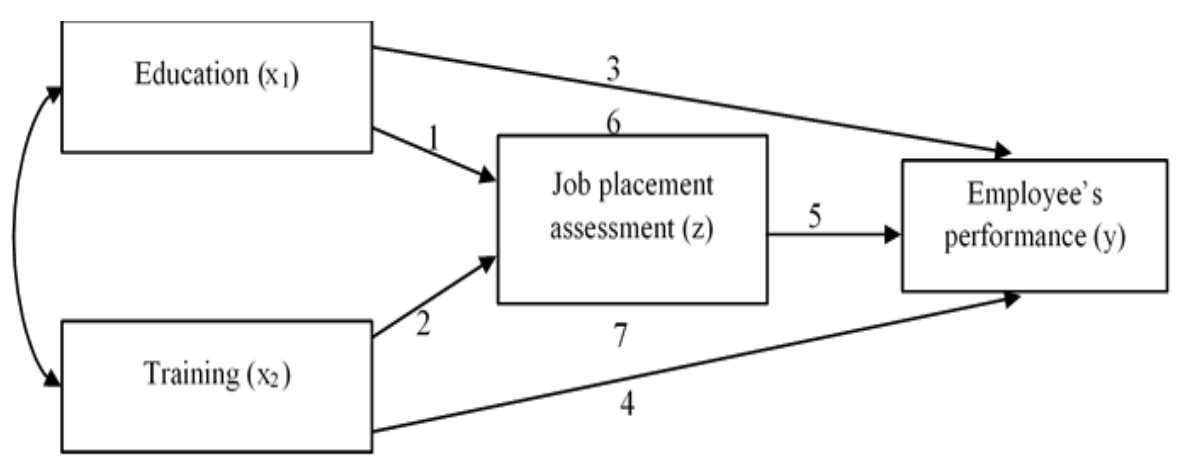

Figure 1. Path model

A total of 2 free variables were researched on the first stage, encompassing education and training, attached with its structural equation as follows:

$$
Z=\beta_{1} X_{1}+\beta_{2} X_{2}+e_{1}
$$

Therefore, step 2 involves research on the 3 free variables including education $\left(\mathrm{x}_{1}\right)$, training $\left(\mathrm{x}_{2}\right)$, job placement assessment $(\mathrm{z})$, using performance $(\mathrm{y})$ as the dependent variable. This forms a structural equation as follows:

$$
Y=\beta_{1} X_{1}+\beta_{3} Z+\beta_{2} X_{2}+e_{2}
$$

Both stages use the quantitative approach, through the path analysis, and analysis was adopted in testing the extent of contribution shown by the correlation coefficient between variable is as follows: (1) Education ( $\left.\mathrm{x}_{1}\right)$ to the job placement assessment (z); (2) Training ( $\left.\mathrm{x}_{2}\right)$ to the job placement assessment (z); (3) Education $\left(\mathrm{x}_{1}\right)$ to the performance $(\mathrm{y})$; (4) Training $\left(\mathrm{x}_{2}\right)$ to the performance (y); (5) Job Placement assessment (z) to the performance (y); (6) Education $\left(\mathrm{x}_{1}\right)$ to the performance $(\mathrm{y})$ through the job placement assessment (z); (7) Training $\left(\mathrm{x}_{2}\right)$ to the performance $(y)$ through the job placement assessment $(\mathrm{z})$.

\section{Results and Discussion}

Figures and This study discusses four variables, where the condition of each is centered on the management of corporate education conducted in two companies, including Gunung Limo and PT. Putra Sarana Transborneo. Furthermore, the mean statistic score achieved for education, training, assessment of work placement and performance were in the medium category, according to three interval groups, encompassing low (less than [mean-1 standard deviation]), medium (mean-1 standard deviation sd mean +1 standard deviation), and high (more than [mean +1 standard deviation]).

The descriptive statistic test result from four variables, stresses the need for further discussion. The education variable in the management of PT. Putra Sarana Transborneo had a value of $63.7 \%$ and subsequently grouped in the middle category. This condition was in line with the opinion of Sedarmiyanti (2009) about programs for learning that play a really important role in increasing the quality and process of reaching an individuals' professional ability. Furthermore, education promotes the preparation towards knowing and developing systematic thought method, in an attempt to help solve problems faced futuristically in life. This further indicates its importance in increasing quality and human competence.

Training in education management at the Gunung Limo Company and PT. Putra Sarana Transborneo possesses a value of $64.9 \%$, which falls into the medium category. This agrees with Rachmawati (2008) where it is viewed as an environmental container for employees, to enhance the acquisition or learning of attitudes, abilities, expertise, knowledge, and specific behaviors related to work. Thus, training is a process to improve competencies to effectively and efficiently carry out work, in an attempt to achieve company goals. Moreover, Mathis and Jackson (2003) reported 
that it encompasses processes where people secure capabilities to aid in the achievement of organizational targets. This, in a limited sense, includes the provision of specific, identified knowledge and skills for use in the present job.

Assessment of work placement in management education in the Gunung Limo company and PT. Putra Sarana Transborneo has a value of $74 \%$, which falls into the medium category. This agrees with the report by Schuler and Jackson (1997), centered on the intent to place the right person in a suitable position, dependent on appropriateness, in terms of knowledge, skills, abilities, and job demands. Furthermore, the assessment of job recruiters implies that employees with an education and have possibly attended training get proper placements. This is attributed based on talents, interests, abilities, and personal conditions, thus eliminating the probability of experiencing obstacles in conducting work.

Performance in education management in the Gunung Limo Company and PT. Putra Sarana Transborneo has a value of $76.6 \%$, which falls into the medium category. This condition agrees with the report by Prawirosentono (2008), where it was affiliated with the extent of work achievable by a person or a group of people in an organization. Furthermore, assessments are conducted following respective authorities and responsibilities, to achieve the legal objectives of the organization, not breaking the law and also following morals and ethics.

Thus, employee performance encompasses the ability to achieve job requirements, where it is possible to precisely complete work targets or where the deadline provided is not exceeded. This also agrees with the study by Pasolong's (2010), which depicts performance as the result of quality and quantity of work, achieved by an individual in conducting their functions, which is following the attributed responsibilities.

The results of testing the research hypotheses, including direct and indirect influences, are obtained through the intermediate variables expressed between the independent and the dependent. Thus, the following conclusions were made from the test results.

\section{The Effect of Education on Work Placement Assessment in the Corporate Education Man- agement Unit}

There is a significant influence of education on work placement assessment that incorporates education within the Gunung Limo Company and PT. Putra Sarana Transborneo, thus, the hypothesis $\left(\mathrm{H}_{1}\right)$ was accepted.

Based on the results, it was established that education affects the assessment of work placements, which was equal to 0.271 . This indicates the influence level of employee education has on the provision of work placements, through placement assessments by the company. Therefore, a better educational background leads to more strategic positioning in an agency. Hence, knowledge helps employees to properly complete work.

This is following the statement of Hasibuan (2010) which portrays the work placement of an employee or workforce through the academic factors considered, owned by the workforce or employees. Furthermore, there is also a need to take specific measures in work placements, to complete assignments, as well as develop authority and responsibility.

Ackerman (2004) revealed several criteria are included when considering a person for the job of a manager such as changes in performance during the placement period, ability to motivate others, milestones accomplished during this tenure, economic impact, and product improvements achieved under the supervision of the manager. When trying to determine the perfect person to fill a vacancy, it's normal to accept new employees or from other divisions. Similarly, when looking for someone within the ranks of the organization, it's ideal to consider those with adequate skills. This process is usually adopted when the company doesn't want to hire from outside.

Training according to the National Education System Law Number 20 the Year 2003 article 1 paragraph 1 , is attributed as a conscious and planned effort to create an atmosphere of learning. Also, the process is in a way that students actively develop the potential to possess religious-spiritual strength, self- 
control, personality, intelligence, noble character, and the skills needed personally, as well as for the community, nation, and state. Furthermore, while conducting work placements in the education management of an organization, an assessment is required, to adjust competence within the predetermined scope. This is following the opinion of Bangun (2012), which stated the relatedness of placement to the adjustment of personal abilities and talents towards the work at hand.

The results of this study are in line with the research conducted by Sunaryo (2016) titled "Effects of Education and Work Placement on Employee Performance at PTPN III Medan". Furthermore, it indicated that (1) education has a significant influence on work placement, and (2) both variables collectively influence performance, significantly. Other researches that were in line with this include the study with the title "Pengaruh Seleksi Terhadap Penempatan (Studi pada Karyawan Bagian Produksi PT. Lieas Tekstil Lawang)". Based on the calculation of descriptive analysis, it is possible to conclude that the variable of employee's placement is the most suitability of formal education background, as well as the application of non-formal forms.

\section{The Influence on Training on Work Place- ment Assessment in the Corporate Education Management Unit}

A significant influence was established between training and work placement assessment in the corporate education management unit of Gunung Limo Company and PT. Putra Sarana Transborneo. This was an indication that the Hypothesis $\left(\mathrm{H}_{2}\right)$ was accepted.

Based on the test results, the effect equals to 0.600 , indicating that participation in more training leads to better job placement, through the appropriate assessment by the company. Besides, the process of training is implicated in the provision of skills that help the company's productivity.

According to Noe et al. (2011), it is attributed as an effort planned by the organization to assist employees obtain work- related knowledge, skills, abilities, and behaviors, to apply this to the job.

Thus, a good placement is observed from work experience through training, which is the key to opening better performance for the company. This practice, therefore, provides placements according to job requirements, to promote working and the propensity to excel. Furthermore, decisions obtained during this assessment process, according to Schuler and Jackson (1997), are intended to place the right person in a suitable position, dependent on the fitness of knowledge, skills, and abilities as well as job demands.

This result was in line with a research from Lumbanraja and Nizma (2010), titled "Pelatihan dan Karakteristik Pekerjaan Terhadap Prestasi Kerja Badan Pelayanan Kesehatan Rumah Sakit Umum Daerah Langsa". This stipulated that training and work characteristics consisting of job significance, autonomy, and feedback influence the performance of nurses in the Langsa Regional Public Hospital Health Service Agency. Furthermore, it is an indication that training and character are needed for supporting achievements. Also, a research-related to the influence of training and employee placement was conducted by Al-Sharafi et al. (2018) in several telecommunication corporations, where it was recognized as a contribution to career development.

\section{The Influence of Education on Performance in the Corporate Education Management Unit}

The findings stated the significant influence of education on performance in education management at the Gunung Limo company and PT. Putra Sarana Transborneo, showing that hypothesis $\left(\mathrm{H}_{3}\right)$ is accepted. Based on the test results, the effect measured was with a value of 0.066 . Thus, an increase in the level of education promotes a significant elevation in employee performance. Furthermore, the outcome is also in line with the research conducted by Pamungkas (2017) titled "The Relationship of Education and Training with Employee Performance in Samarinda City Industry and Trade Office". This discussed 
implementations in the Department of Industry and Trade.

Also, a relationship was established with the results obtained from Rori et al. (2014), titled "Education, Training and Work Placement Impacts on Employee Performance in the Manado City Inspectorate Office". This indicated that the education variables confer a positive and significant effect on employee performance, indicating the importance of education in the improvement if performance in the Manado City Inspectorate Office, fostering the conduction of basic tasks and functions. Other related studies include the Kandow, Kawet, and Alumni research, entitled "The Effect of Education, Training and Job Placement to Employees Performance of PT. PLN (Persero) Manado Area ", where the results identified a significant and good effect of training on employee performance at the PT. PLN (Persero) in Manado.

\section{The Influence of Training on Performance in the Corporate Education Management Unit}

The findings stipulated the significant effect of training on performance in education management within the Gunung Limo Company and PT. Putra Sarana Transborneo, thus the hypothesis $\left(\mathrm{H}_{4}\right)$ is accepted.

The test results indicate an effect with the value of 0.097 , based on interviews with employees, thus, training held by the company's management unit confers a significant influence.

Furthermore, a reason expressed was the fact that the training materials are taught accordingly, hence the output is better optimized. Besides, a similar condition was expressed, under the respondents' answers through questionnaires distributed to the study sample. Moreover, the statement therein reads "material given when training is very helpful for employees to complete work". This was consistent with the reports stipulating the significant direct effect of training on performance.

Mangkunegara (2004) stated that its purpose was geared towards optimally improving the ability to perform. This case, therefore, shows the influence of the training held at PT. Gunung Limo and PT. Sarana Putra Transborneo on employee performance.
The results obtained from research by Rori et al. (2014) titled "Education, Training and Work Placement Impacts on Employee Performance in Manado City Inspectorate Office", was also in line with the current study outcome. Besides, it is shown that variables confer a significant positive effect in the Manado City Inspectorate Office, implicating it as a very important tool. This is possibly interpreted that training obtained helps in the conduction of basic tasks and functions. Also, the data showed the tendency of improvement in the number of employees participating. This is affected by the type of training attended, its management, materials provided, and the evaluation of its implementation.

Similar research was performed by Halawi and Haydar (2018), in two companies situated in Libanon, encompassing Bonjus as well as Khatib and Alami. Furthermore, the outcome stipulated the positive impact of conducting training on performance, especially in the aspect of understanding the job description, in an attempt to prompt the reach for the job's target. Motlokoa et al., (2018) studied several banks in Lisoto, with the involvement of 171 respondents, and it was identified that training serves both as a positive impact and a source for motivating employees. Also, research on bankers was performed by Afroz (2018) in 14 banks situated in Bangladesh, involving 150 employees or bankers. Thus, a strong relationship was established between training and their performance.

Factors that affect the performance achievement of any organization are ability and motivation. These are in line with the opinions of Mangkunegara (2004), as follows:

a. Ability Factor

Employees' abilities consist of IQ, knowledge, and skills. An employee with IQ above average (IQ 110-120), adequate education for their position, and skilled in carrying out their daily work are expected to achieve great performance. Therefore, employees need to be placed in jobs that match their expertise.

b. Motivation Factor This is formed from the attitude of an employee is facing a situation at work. 
Motivation is the condition that moves an employee into achieving the necessary organization's goals.

Previously, a research performed by Imran and Tanveer (2015) in several banks within Pakistan concluded on the positive impact of qualitatively and quantitatively training on the employee's understanding of job specification, and the influence on personal performance. A similar result was estimated by Kum et al. (2014) in Escon, consulting in Africa, which confirmed the ability to increase the workers' performance with implications to enhance productivity. This was in line with a study by Elnaga and Imran (2013), which identified the ability for training to promote the act of being nimble while performing assigned tasks, subsequently enhancing the readiness to work harder or obtain a higher position.

\section{The Influence of Work Placement Assessment on Performance in the Corporate Education Management Unit}

The findings of this study stipulate a significant effect of work placement assessment on performance in the education management in Gunung Limo companies and PT. Putra Sarana Transborneo, thus, the hypothesis $\left(\mathrm{H}_{5}\right)$ was accepted. This was ascertained based on the value obtained, being equal to 0.315 .

Furthermore, based on assessment references were made towards the indicators of knowledge suitability, in areas where work placements provided to employees are following their educational background, within the insights of knowledge, and the appropriateness of the field of work. Besides, another indicator is the suitability of the skills possessed, and its ability to support the processes of completing tasks obtained from superiors. Also, the suitability of attitudes is another marker that serves as a technical breakthrough regarding the implementation of work. This provides a perception that the attributed task is following the capabilities possessed, to promote the completion of every job described.

Pramista (2016) entitled "The Effect of Education, Training and Work Placement Levels on Employee Productivity in KPP Pratama
Pare" shows the following outcomes: (1) education; (2) training; (3) work placement; and (4) a collection of all three tend to significantly influence employee work productivity.

The results are in line with the research by Weol's (2015), under the title "The Effect of the Work Environment, Training, and Placement on Employee Performance in the National Education Office of North Sulawesi Province". Furthermore, the conclusions drawn stated that (1) the work environment confers an impact on employee performance, with a significant coefficient value that includes a positive, comfortable, pleasant, and complete environment; (2) a similar effect is observed with training; and (3) the placement, which is specifically ascertained through merits of academic achievement, work experience, physical and mental health, marital status and age.

Rori et al. (2014) also agree with the study outcome, based on the report titled "Education, Training and Work Placement Impacts on Employee Performance in Manado City Inspectorate Office". This stipulated the positive and significant impact of the work placement variable on performance within the Manado City Inspectorate Office. Furthermore, there are indices that this factor plays an important role under academic achievement, work experience, health tests, attitudes and age of the employee concerned.

Other reports that support this opinion include an investigation conducted by Khaerudin et al. (2018), where it was established that a placement and competency tests positively and simultaneously affect the performance of workers in the Indonesian Ministry of Defense. Also, Kurniawan et al. (2018) conducted a similar study at PT. Bank Capital Indonesia, and demonstrated the occurrence of a significant effect, while Kadiresan et al, (2015) identified the optimistic influence of performance appraisal and training, during the assessment of various companies in Malaysia.

The opinions stated by Mahmudi (2005), are as follows:

a. Personal factors include knowledge, ability, confidence, motivation, and commitment by workers. 
b. Leadership factor is the act of providing support, spirit, and direction, by the leader.

c. The team factor is the support quality, trust, and spirit provided by each member. This leads to the uniformity and compactness of a team.

d. The system factor analyzes the organization's system, instructions processes, and work culture of how the organization is run

Similar result research by Abbas (2014), with regards to performance appraisals conducted in several companies situated in Pakistan, also showed a positive influence. Furthermore, explanations were conveyed from the report of Kyeremeh and Pimpong (2018), where it was identified to confer an increase in the commitment of employees to work better. This was also the outcome of the research conducted by Ehsan (2018) in Pakistan, where 100 employees of the telecommunications industry were obtained as a research sample. Furthermore, Butali and Njoroge (2016) attested that the effect is not limited to individual employees, but also an enormous impact on the overall organizational performance.

The Influence of Education on Performance Through the Work Placement Assessment in The Corporate Education Management Unit

The findings stated the effect of education on performance through work placement assessments in education management at the Gunung Limo and PT. Putra Sarana companies, thus the hypothesis $\left(\mathrm{H}_{6}\right)$ is accepted.

Based on the results, the effect of conferred equals a value of 0.085 , which is attributed as meaningful. This is an indication that the level of education obtained by the employee in the process of job positioning, through placement assessment influences performance. This was in line with a study by Siagian (2003), as expressed in the theory of human resource management, where it was established that work placement applies both to new and old employees with changed assignments and mutations in position within a company. Besides, the propensity of being accepted into an organization or company requires the successful completion of the assessment process. This is an advantage that places employees in the right position, and subsequent stages require performance evaluation by superiors. Yuniarsih and Suwatno (2012) stipulated the need for considering the minimum educational factors required during this process.

Furthermore, the results from this current investigation agreed with Sunaryo (2016), entitled "Effects of Education and Work Placement on Employee Performance at PTPN III Medan" where it was noted that: (1) Education; (2) work placement; and (3) a simultaneous collection of both impacts significantly on employee performance. Ishola and Adeleye (2018) at a university in Nigeria showed the impact of educational background, as employees with a higher level were reported to perform better. Furthermore, similar results were obtained by Kotur and Anbazhagan (2014), conducted at the Chittoor Sugar Factory in South India, where education and work experience directly influenced employee performance at the sugar factory.

\section{The Influence of Training on Performance Through the Work Placement Assessment in The Corporate Education Management Unit}

The research findings stated the effect of training on performance, obtained through work placement assessments in education management of Gunung Limo and PT. Putra Sarana Transborneo companies. Thus, the hypothesis $\left(\mathrm{H}_{7}\right)$ was accepted. Furthermore, an influence value equal to 0.189 was recorded, indicating the influence of training through placement assessment on employee performance.

Therefore, agrees with Mondy (2008), which stated its tendency to provide learners with the knowledge and skills required for the respective work. Besides, the process was also conducted to align the participants' potential with company strategies, fostering a close relatedness to the goals, and enhanced performance as the ultimate target for the training process. Training determines the right pattern following the technicalities concerned, mechanisms, and procedures. This is also following the applicable organizational structure, as well as the impact of authorized, capable, skilled, and professional officers in the process, which is following task specifications, 
through the placement of duties. This also includes the consideration of optimizing the use of infrastructure, in an attempt to support technical training.

An employee that has obtained the relevant training, and can match the work demands is expected to have a positive disposition as regards performance. According to Yuaniarsih and Suwatno (2012), placements ought to take into consideration the skills or expertise for work, gained in practice (training).

The result obtained from analyzing the data of the research by Astuti and Bukhari (2018), titled "Employee Performance Analysis of PT. Tirta Investama "formulated that the following: (1) the training partially confers a significant effect on performance; (2) work placement has no influence; and (3) the combination of both significantly impacts on employee performance.

Sari (2018), with the title "The Effect of Training and Work Placement on Employee Performance" reported the significant influence of employee training and work placement on performance within the Education Office of the city of Lubuklinggau. This was also in line with the study by Fitasari (2016), titled "The Effect of Competence on Employee Performance with Appropriate Placement as an Intervening Variable (Empirical Study of Managerial Level Employees in Manufacturing Companies in Cikarang)". Furthermore, the results stipulated the impact of competence, with job placement suitability as an intervening variable. Besides, there was also a higher propensity to place a managerial level employee with good competence at the appropriate position (job replacement), to produce optimized output, else this prospect becomes unattainable.

\section{Conclusion and Recommendation}

From this research result and discussion, the following impacts were established:

1. There is an effect of education work placement assessment in the corporate education management unit.

2. There is an effective training to work placement assessment in the corporate education management unit.
3. There is an effect of education to employee's performance.

4. There is an effective training to employee's performance.

5. There is an effective work placement assessment on performance in the corporate education management unit. Furthermore, the report also shows.

6. There is an effect of education to employee's performance through work placement assessment in the corporate education management unit.

7. There is an effective training on the employees' performance, through work placement assessment in the corporate education management unit.

Besides, some suggestions to be delivered to the company include, (1) Corporate education management, especially in the areas of resource development needs to pay attention to this study finding, during an attempt to increase employee performance. This is possibly achieved by focusing on attributing placements based on educational background, improving training quality, and assessments; (2) Enhancing the education implementation, and the training process ought to be managed by a dedicated corporate education unit. This is conducted to improve skills and develop the employees' abilities and competence, and also paying attention to other related essential elements. Therefore, proper practice of management, and conditionin competent employees with adequately developed skills, promotes the actualization of best performances.

\section{Acknowledgment}

The author would like to thank you for supporting this research especially all employees in PT. Gunung Limo and PT. Putra Sarana Transborneo, and Education Management Master Program, Universitas Lambung Mangkurat.

\section{References}

Abbas, M. Z. (2014). Effectiveness of performance appraisal on performance of employees. IOSR Journal of Business and Management, 16(6), 173178. 
Ackerman, L. D. (2004). Identity is destiny: Leadership and the roots of value creation. Jakarta: Gramedia.

Afroz, N. N. (2018). Effects of training on employee performance - A study on Banking sector, Tangail Bangladesh. Global Journal of Economicsand Business, 4(1), 111-124.

Aldilaningsari, Y., Musadieq, M. A., \& Hakam, M. S. (2014). Pengaruh penempatan kerja terhadap kinerja: Studi pada Karyawan PT. Bank Jatim cabang Malang. Jurnal Administrasi Bisnis, 9(1), 1-7.

Al-sharafi, H., Hassan, M. E., \& Alam, S. S. (2018). The effect of training and career development on employees retention - A study on the Telecommunication Organizations in Yemen. The Journal of Social Sciences Research, 2, 420-430. doi:10.32861/jssr.spi2.420.430

Astuti, M. W., \& Bukhari, E. (2018). Analisis kinerja pegawai PT. Tirta Investama. Jurnal Riset Manajemen Sains Indonesia, 9(1), 22-36.

Bangun, W. (2012). Manajemen sumber daya manusia. Jakarta: Erlangga.

Butali, P., \& Njoroge, D. (2016). Effect of performance appraisal on organizational performance. International Journal of Science and Research, 7(9), 685-690. doi:doi: 10.21275/ART2019724.

Chaerudin, A. (2019). Manajemen pendidikan dan pelatihan SDM. Bandung: Jejak.

Ehsan, H. (2018). Impact of performance appraisal, work design and compensation on employee performance: A study of Telecom Sector. Journal of Global Economics, 6(3), 1-9. doi:10.4172/23754389.1000301

Elnaga, A., \& Imran, A. (2013). The effect of training on employee performance. European Journal of Business and Management, 5(4), 137-147.

Fitasari, E. (2016). Pengaruh kompetensi terhadap kinerja karyawan dengan kesesuaian penempatan sebagai intervening variable: Studi empiris terhadap karyawan level manajerial pada perusahaanperusahaan manufacturing di Cikarang. Jakarta: Universitas Terbuka.

Halawi, A., \& Haydar, N. (2018). Effects of training on employee performance: A case study of Bonjus, Khatib and Alami companies. International Humanities Studies, 5(2), 24-45.

Hasibuan, M. S. (2010). Manajemen sumber daya manusia. Jakarta: PT. Bumi Aksara.

Imran, M., \& Tanveer, A. (2015). Impact of training and development on employees' performance in Banks of Pakistan. European Journal of Training and Development Studies, 3(1), 22-44.
Ishola, A. A., \& Adeleye, S. T. (2018). Impact of educational, professional qualification and years of experience on accountant's job performance. Journal of Accounting and Financial Management, 4(1), 32-44.

Kadiresan, V., Selamat, M. H., Selladurai, S., Ramendran, C., \& Mohamed, R. K. (2015). Performance appraisal and training and development of human resource management practices (HRM) on organizational commitment and turnover intention. Asian Social Science, 11(24), 162-172.

Khaerudin, Rivai, A., \& Riyanto, M. (2018). The effect of placement and competency on performance through employee commitment in Financial Center Office Ministry of Defense Indonesia. IOSR Journal of Business and Management, 20(2), 54-61.

Kotur, B. R., \& Anbazhagan, S. (2014). Education and work experience influence on the performance. IOSR Journal of Business and Management, 16(5), 104110.

Kum, F. D., Cowden, R., \& Karodia, A. M. (2014). The impact of training and development on employee performance: A case study of Escon Consulting. Singaporean Journal of Business Economics and Management Studies, 3(3), 72-105.

Kurniawan, A., Rivai, A., \& Suharto. (2018). Effect of employee placements and competency on employee performance through motivation in PT. Bank Capital Indonesia TBK branch of Kuningan Tower Jakarta. Scholars Journal of Economics, Business and Management, 5(2), 126-135. doi:10.21276/sjebm.2018.5.2.6

Kyeremeh, D. D., \& Pimpong, M. (2018). Performance appraisal and staff commitment in higher education. Asian Research Journal of Arts \& Social Sciences, 7(2), 1-14.

Lumbanraja, P., \& Nizma, C. (2010). Pelatihan dan karakteristik pekerjaan terhadap prestasi kerja badan pelayanan kesehatan Rumah Sakit Umum Daerah Langsa. Jurnal Manajemen dan Kewirausahaan, 12(2), 142-155.

Mahmudi. (2005). Manajemen kinerja sektor publik (1st ed.). Yogyakarta: UUP AMP.

Mahsun, M. (2006). Pengukuran kinerja sektor publik. Yogyakarta: BPFE Yogyakarta.

Mangkunegara, A. P. (2004). Manajemen sumber daya manusia perusahaan. Bandung: PT. Remaja Rosda karya.

Mangkunegara, A. P. (2010). Evaluasi kinerja SDM. Jakarta: PT. Refika Aditama.

Mangkuprawira, S. (2011). Manajemen sumber daya manusia strategik. Jakarta: Ghalia Indonesia. 
Mathis, R. L., \& Jackson, J. H. (2003). Human resource management. Ohio: Thomson South-Western.

Mondy, R. W. (2008). Human resource management (10th ed.). Jakarta: PT. Gelora Aksara Pratama.

Motlokoa, M. E., Sekantsi, L. P., \& Monyoloc, R. P. (2018). The impact of trainings on employees' performance: The case of Banking Sector in Leshoto. International Journal on Human Resources Studies, 8(2), 16-46. doi:10.5296/ijhrs.v8i2.12812

Noe, R. A., Hollenbeck, J. R., Gerhart, B., \& Wright, P. M. (2010). Human resource management: Gaining a competitive advantage. Boston: McGraw Hill.

Pamungkas, G. I. (2017). Hubungan pelatihan dan pendidikan dengan kinerja pegawai di Dinas Perindustrian dan Perdagangan Kota Samarinda. Journal Administrasi Negara, 5(3), 6607-6620.

Pasolong, H. (2010). Teori administrasi publik. Bandung: Alfabeta.

Pesiwarissa, E. L. (2008). Pengaruh kesesuaian penempatan kerja terhadap prestasi kerja: Studi pada pegawai Kantor BAPPEDA kabupaten Nabire, Papua. Jurnal Aplikasi Manajemen, 6(1), 23-37.

Pramista, A. D. (2016). Pengaruh tingkat pendidikan, pelatihan dan penempatan kerja terhadap produktivitas kerja pegawai KPP Pratama Pare. Jurnal Ekonomi Manajemen, 7(2), 5-10.

Prawirosentono, S. (2008). Kebijakan kinerja karyawan. Yogyakarta: BPFE.

Presiden Republik Indonesia. (2003). Undang-undang Republik Indonesia nomor 20 tahun 2003 tentang sistem pendidikan nasional. Jakarta: Pemeritah Republik Indonesia.
Rachmawati, I. K. (2008). Manajemen sumber daya manusia. Yogyakarta: Andi Press.

Riyanto, A., Raspati, G., \& Nugraha, R. (2017). Impak penempatan kerja terhadap kinerja karyawan pada kantor pusat PDAM kabupaten Sukabumi. Jurnal Swabumi, 5(2), 132-136.

Rori, W. J., Mekel, P. A., \& Imelda., O. (2014). Pendidikan, pelatihan dan penempatan kerja pengaruhnya terhadap kinerja pegawai di Kantor Inspektorat Kota Manado. Jurnal EMBA, 2(2), 1284-1295.

Sari, W. M. (2018). Effect of training and work replacement on performance of employees. Journal of Economic, Business and Accounting, 2(1), 149-162.

Schuler, R. S., \& Jackson, S. E. (1997). Manajemen sumber daya manusia menghadapi abad ke 21. Jakarta: Erlangga.

Sedarmiyanti. (2009). Sumber daya manusia dan produktivitas kerja. Bandung: CV. Mandar Maju.

Siagian, S. P. (2009). Manajemen sumber daya manusia. Jakarta: Bumi Aksara.

Siswanto, B. (2002). Manajemen tenaga kerja. Bandung: Sinar Baru.

Sunaryo. (2016). Pengaruh pendidikan dan penempatan kerja terhadap kinerja pegawai di PTPN III Medan. Jurnal Ilmiah Manajemen dan Bisnis, 17(1), 88-100.

Tika, P. (2014). Budaya organisasi dan peningkatan kinerja perusahaan. Jakarta: Bumi Aksara.

Weol, D. H. (2015). Pengaruh lingkungan kerja, pelatihan dan penempatan terhadap kinerja pegawai di Dinas Pendidikan Nasional provinsi Sulawesi Utara. Jurnal Berkala Ilmiah Efisiensi, 15(5), 598-609.

Yuniarsih, T., \& Suwatno. (2012). Manajemen sumber daya manusia. Bandung: Alfabet 